\title{
PLACES WHERE FAMOUS OPHTHALMOLOGIST ALBRECHT VON GRAEFE LIVED AND WORKED IN BERLIN
}

\author{
MJESTA U KOJIMA JE GLASOVITI \\ OFTALMOLOG ALBRECHT VON \\ GRAEFE ŽIVIO I RADIO U BERLINU
}

\author{
Milan Ivanišević*
}

\begin{abstract}
SuMMARY
Many things are said and written about famous ophthalmologist Albrecht von Graefe. This work gives detailed description of the places where he lived and practiced ophthalmology in Berlin, because very little was written about it and never in one paper.

Von Graefe was born in 1828 in villa Finkenherd in the north-west part of Tiergarten in Berlin. He lived in Behrenstrasse, one of the fashionable streets in Berlin, where he began his ophthalmological practice in 1850 . Later, in 1852 he founded a famous private eye clinic in Karlstrasse 46 where he treated numerous eye patients and educated many prominent ophthalmologists and surgeons. Several times he had changed his residence addresses. Among other places, he also stayed in Unter den Linden Avenue and Bellevuestrasse near Potsdamer Platz. In I868 he became the head of the eye clinic in the Charité Hospital. Since then he lived in a spacious house on Viktoriastrasse until his death in 1870.

Although Albrecht von Graefe lived only 42 years, he travelled a lot, but most of his life he spent in the city of Berlin. Graefe made many contributions to ophthalmology being considered the "father of glaucoma" and the nestor of modern ophthalmology.
\end{abstract}

Keywords: Albrecht von Graefe, ophthalmology, history, Igth century, Berlin

* Correspondence Address: Milan Ivanišević, Department of Ophthalmology, University Hospital of Split, University of Split School of Medicine, Spinčićeva 1, 21000 Split, Croatia.E-mail: milan.ivanisevic@kbsplit.hr. 


\section{SCIENTIFIC CAREER}

Albrecht von Graefe (1828-1870) was the nestor of modern ophthalmology, the one who separated ophthalmology from surgery and one of the greatest ophthalmologists of all times. He spent ophthalmological education in Prague (Ferdinad von Arlt, who introduced him to ophthalmology), Vienna (Friedrich and Eduard von Jaeger), Paris (Auguste Desmarres, Julius Sichel), London (William Bowman, George Critchett), Glasgow (William Mckenzie), and Dublin (William Wilde). ${ }^{1}$ He founded a private eye clinic in Berlin in 1852 , which became the most famous eye clinic in the rgth century. Many well-known ophthalmologists were educated in his clinic. ${ }^{2}$ Von Graefe was the first to introduce iridectomy in acute glaucoma treatment (1856). ${ }^{3}$ In 1865 he created a special surgical knife for cataract, which is named after him, making a great improvement in cataract surgery. This knife was in widespread usage for the next one hundred years. ${ }^{4} \mathrm{He}$ was also the first to use Helmholtz' ophthalmoscope routinely in $185 . .^{5} \mathrm{He}$ was the first to describe glaucomatous cupping, retinal artery embolism, optic neuritis, papilloedema in brain tumour, and retinal glioma. In 1856 he designed and used an instrument for clinical perimetry. ${ }^{6}$ Von Graefe designed the first tonometer to attempt to measure the intraocular pressure in $1862 .{ }^{7}$ In 1854 he founded the world's first ophthalmological journal the Archive für Ophthalmologie, which still exists today under the name Graefe's Archive for Clinical and Experimental Ophthalmology. In 1863 he founded the German Ophthalmological Society in Heidelberg, which was the first ophthalmological society in the world. ${ }^{8}$ At the age of 29, he became an associate professor of ophthalmology, the first with such a title in Germany. From 1868 to 1870 he was a head of the eye

1 Duke-Elder S. (1969) Diseases of the lens and vitreous; Glaucoma and hypotony. System of Ophthalmology; London: Henry Kimpton, 11, p. 615.

2 Remky H. (1995) Albrecht von Graefe. Facets of his work. On the occasion of the 125th anniversary of his death (20 July 1870). Graefes Arch Clin Exp Ophthalmol., 233(9):537-48.

3 Goldmann H. (1971) Albrecht von Graefe and glaucoma. Graefes Arch Clin Exp Ophthalmol., 181(2):94-106.

4 Wachholz EA. (1972) Cataract knife and cataract incision from Jean Jacques Daviel to Albrecht von Graefe. Ber Zusammenkunft Dtsch Ophthalmol Ges., 71:709-12.

5 Ravin JG. (1999) Sesquicentennial of the ophthalmoscope. Arch Ophthalmol., 117(12):1634-8.

6 Harms H. (1971) The importance of Albrecht von Graefe's work on the examination of the visual field. Graefes Arch Clin Exp Ophthalmol., 181(2):120-9.

7 Draeger J. (1993) Principles of measurements in tonometry at the time of Albrecht von Graefes to D2 mission and self-tonometry. Klin Monatsbl Augenheilkd., 202(1):2-7.

8 Auffarth GU, Krogmann F. (2018) Die Zukunft im Blick: 150 Jahre UniversitätsAugenklinik Heidelberg. Heidelberg: hei BOOKS, p. 49. 
clinic in the Charité Hospital. Despite his relatively short life, he greatly contributed to the development of scientific ophthalmology. ${ }^{9}$

\section{LIVING PLACES}

Albrecht von Graefe was born on the $22^{\text {nd }}$ of May, 1828 in his family summer villa Finkenherd (Haunt of Finches) in the north-west part of Tiergarten in Berlin, Hansaviertel district today (Figure I). He was the son of Carl Ferdinand von Graefe (I787-I840) and Auguste, born von Alten. His father was a director of the surgical and eye clinic in Berlin and a physician to the general staff of the Prussian army. ${ }^{10}$

Villa Finkenherd was built on the land given by the Prussian king Friedrich Wilhelm III (1770-1840) in 1824. The architect of that country house was famous Friedrich Schinkel (I78II84I). Garden decoration plan was created by a landscape architect and garden artist Peter Lenné (I789-1866) (Figure 2). The villa was sold in 1854 and changed many owners since then. In I880 it became cafe-restaurant Charlottenhof. The building was restored in 1935. It was destroyed during bomb-

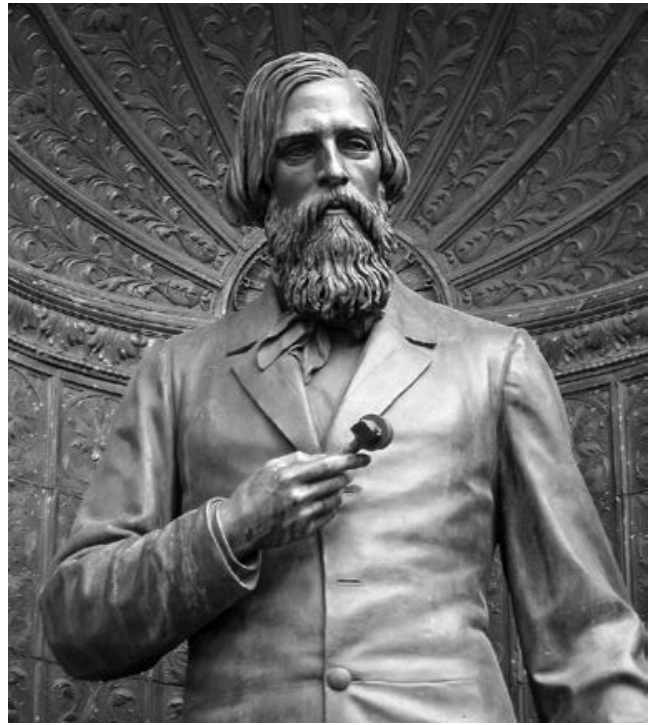

Figure I. Albrecht von Graefe (I828-1870), a detail from the monument in front of the Charité Hospital in Berlin, erected in 1882. ing on the night of $22-23$ of November 1943. Today, on that place there is a memorial plaque set in 1970. It was made by the sculptor Edzard Hobbing (1909-I974). ${ }^{11,12}$

9 Kerr C. (2008) Scientific ophthalmology owes its beginnings to short life of Albrecht von Graefe. Eurotimes, 13:54.

10 Jähne M. (1988) Carl Ferdinand von Grefe (1787-1840) und seine Relevanz für die Augenheilkunde. Klin Monatsbl Augenheilkd., 193(3):310-4.

11 Hoffmann-Axthelm W. (1979) Die Familie von Graefe und ihre Villa Finkenherd im Berliner Tiergarten. Mitteilungen des Vereins für die Geschichte Berlins., 66(21):322-34.

12 Rohrbach JM. (2013) Albrecht von Graefe. In: Schilp T, Rohrbach JM (eds.). Albrecht von Graefe an Frans Cornelis Donders: Briefe 1852 bis 1970. Essen: Klartext, p. 21-56. 
During the winter the family von Graefe lived in a beautiful and spacious house in Behrenstrasse 48 . His father and the family lived there since 1823 (Figure 3$).{ }^{13}$ Later on, the house in Behrenstrasse 48 was owned by a banker Robert Warschauer (1856) and in I9Io was restored and Kerkau palace was built in which was a restaurant. Today, on its place stands a modern building with fitness and wellness facilities.

In 1853 he rented a big apartment in Unter den Linden, at number 6 . He lived there until 1858. His friend and assistant Adolf Schuft lived with him in I858. ${ }^{14}$

Since Igro there was the east wing of the Bristol Hotel there. Today, the west part of the

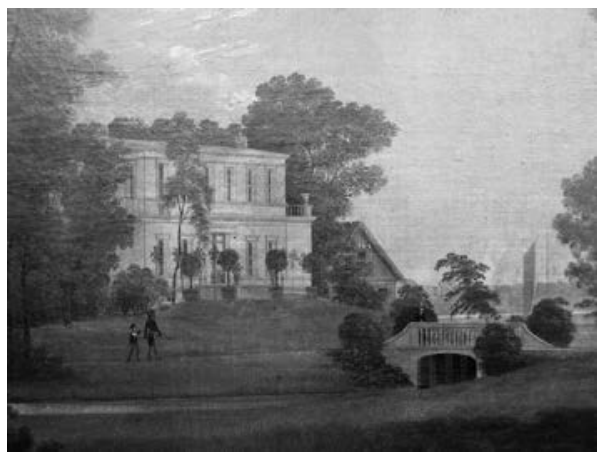

Figure 2. Villa Finkenherd, a view from the south-east, 1839 .

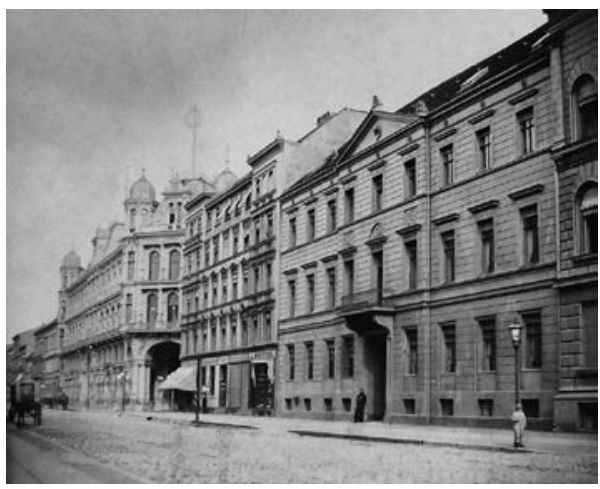

Figure 3. Behrenstrasse 48, 1874 . Russian Embassy courtyard is situated on that place.

In 1858 Graefe moved together with his colleague Schuft in Behrenstrasse 72 until I86I, and after that stayed there with his wife Danish Countess Anna von Knuth from I862 to $1865 .{ }^{15}$ Today, Bundestag offices are placed there.

From 1866 to 1868 , he lived with his family in a vast and nice house in Bellevuestrasse 16 . It was called the Casper House, built in 1837 by the architect Eduard Knoblauch (I80I-I865). ${ }^{16}$ The building was demolished, and on that place in 1912 was built the north-west wing of the Esplanade Hotel.

13 Ullman EV. (1954) Albrecht von Graefe: The man in his time. Am J Ophthalmol., 38(4):525-43.

14 Heynold von Graefe B. (1991) Albrecht von Graefe-Mensch und Umwelt. Berlin: Stapp Verlag., p. 89.

15 Hoffmann-Axthelm W. (1979) Die Familie von Graefe und ihre Villa Finkenherd im Berliner Tiergarten. Mitteilungen des Vereins für die Geschichte Berlins., 66(21):322-34.

16 Ullman EV. (1954) Albrecht von Graefe: The man in his time. Am J Ophthalmol., 38(6):791-809. 
Today there stands the north-east entrance of the Sony Centre in the same street on the Postdamer Platz.

In April 1868 von Graefe moved to a spacious house on Viktoriastrasse 34, which was at a short distance from Bellevuestrasse 16 . He lived there until his death on the $20^{\text {th }}$ of July 1870 , and his wife Anna with their three kids until $1872 .{ }^{17}$ The house was built in 1858 and the architect was Friedrich Hitzig (I8II-188I) (Figure 4). The distance between the house and the clinic in Karlstrasse was about 1600 meters and he usually came back from work by a coach across Tiergarten. The building was destroyed during bombing in the World War II. Today that place is 70 meters south-east of the Berlin Philharmonic, on the street Ben Gurion.

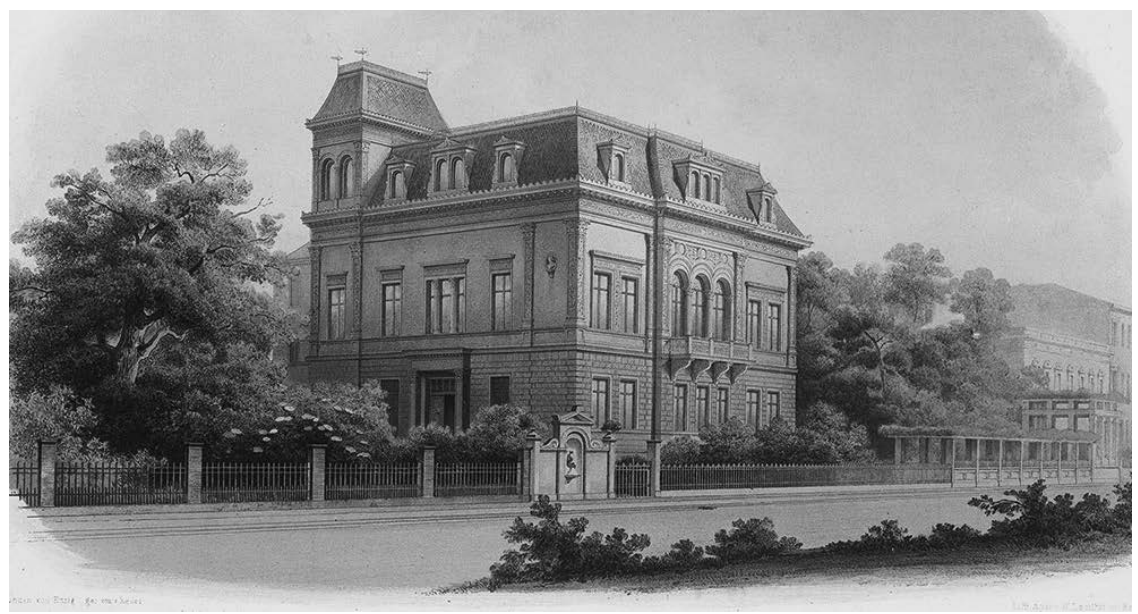

Figure 4. Viktoriastrasse 34, a house where A. von Graefe lived from I868 and died in 1870 .

\section{WORKING PLACES}

After three years of his European educational travels, von Graefe opened his first eye clinic in Berlin, in a rented simple apartment on the second floor of a small house in Behrenstrasse, number 52, on the first of November, 1850. He used to work there for two years. ${ }^{18}$ Later on, in 1873 it was the south front of the Kaisergalerie. Today, that is the place on the south front of The Westin Grand Hotel, to the left of the main entrance.

17 Herde J. (2007) Die Nachfahren der von Graefe- und Graefe-Familien. In: Deutsche Ophthalmologische Gessellschaft (ed.). Visus und vision-150 Jahre DOG. Köln: Biermann Verlag GmbH., p. 309-53.

18 Hirschberg J. (1906) Albrecht von Graefe. Leipzig: Wilhelm Weicher, p. 19. 
Because of the tiny space in Behrenstrasse 52, he performed major operations in Johannisstrasse I2. There he had two rooms which he rented from a man's tailor C. F. Groth. ${ }^{19,20}$

In 1852 the clinic is moved to Karlstrasse 46 where he worked until his death in $1870 .{ }^{21}$ That private eye clinic was a model for many eye clinics in Europe in the igth century (Figure 5). It was angle shaped three-storey building. The clinic could take in more than hundred patients. It had clinical departments, teaching rooms and operating theatres. ${ }^{22}$ From 1859 to 1865 , the clinic was situated at house numbers $45-46$, and from $1866-1870$ at house numbers $42-46$.

Many ophthalmologists and surgeons were educated in his clinic. The well-known are: Argyll Robertson (1837-1909), Theodor Billroth (1829-1884), Theodor Leber (1840-1917), Friedrich Horner (I83I-1886), Julius Hirschberg (1843-1925), his cousin Alfred Karl Graefe (1830-1899). ${ }^{23}$

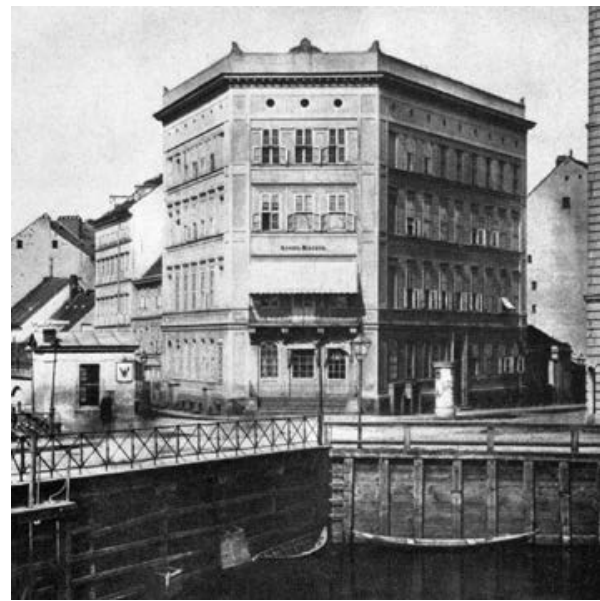

Figure 5. Graefe's private eye clinic at Karlstrasse 46 in Berlin, before I870.*

According to his wish, the clinic was definitely closed after his death. The building was damaged in the World War II, but the remains survived until the building of the Berlin Wall. It was demolished at the end of 1970 . $^{24}$ Today, on its place stands a modern office building, made in 2004 similar in appearance to the one on the address Reinhardtstrasse $56-58$, on the east side of Kronprinzenbrücke on the river Spree.

From 1868 to 1870 , full professor Albrecht von Graefe was a head of the eye clinic in the Charité hospital (Figure 6). ${ }^{25}$ Graefe still held his clinical exercises during the winter

\footnotetext{
Michaelis E. (1877) Albrecht von Graefe. Sein Leben und Wirken. Berlin: G. Reimer, p. 35.

20 Snyder C. (1965) Dr. Albrecht von Graefe in Behrenstrasse will treat free of charge the eye diseases of the poor. Arch Ophthalmol., 74(4):545-8.

21 Münchow W. (1978) Albrecht von Graefe. Leipzig: BG Teubner Verlagsgesellschaft, p. 60.

22 Samelson A. (1866) Von Graefe's Eye Clinic. Am J Med Sci., 52(103):259-61.

23 Tan SY, Zia JK. (2007) Albrecht von Graefe (1828-1870): founder of scientific ophthalmology. Syngapore Med J., 48:797-8.

24 Kazimirski J. (1995) Albrecht von Graefe Augenklinik. Ophthalmo-Chirurgie, 7:171-9.

25 Cooper SN. (1970) Editorial. Albrecht von Graefe. Indian J Ophthalmol., 18(4):150-3.
} 


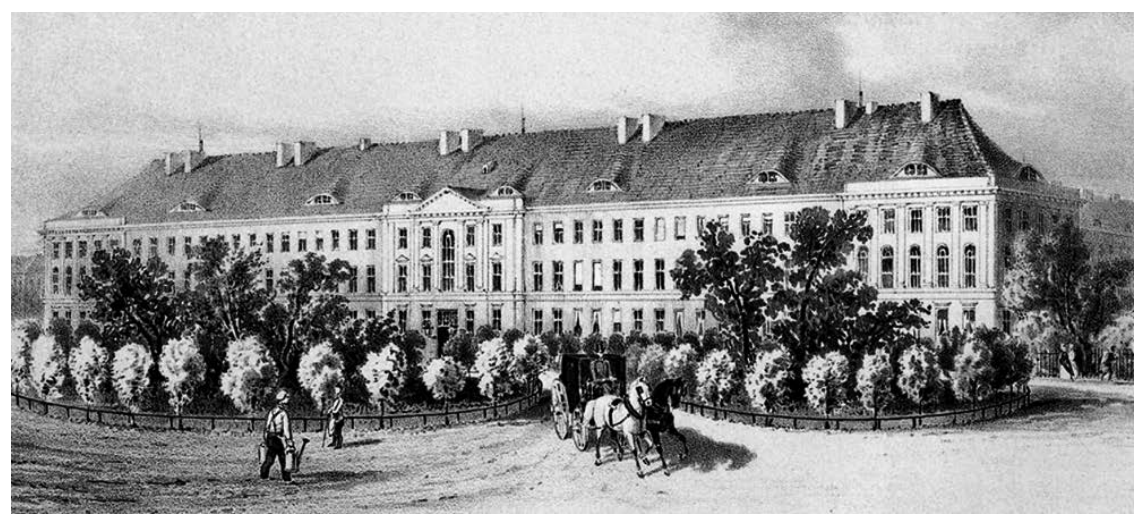

Figure 6. Charité Hospital around I850.

semester of $1868 / 1869$ in his own private eye clinic and he moved during the summer semester in 1869 to the Charité and gave the official lectures there. The examinations in ophthalmology became an essential part of the medical requirements in $1868 .{ }^{26}$

\section{BURIAL SITE AND CONCLUSION}

Von Graefe died from pulmonary tuberculosis in Berlin in 1870 . His burial place is on the Jerusalem and New Church cemetery II in Kreuzberg area of Berlin, south of Hallesches Tor. Later on, his wife was buried there too, and much earlier his father and mother. On his tombstone are inscribed the simple words "The teacher of ophthalmology" and those whom he saved from blindness can read the biblical statement "Light is sweet and it is pleasant for the eyes to see the sun." 27

Although he lived only 42 years, he travelled a lot, but most of his life he spent in the city of Berlin. Through his short career, he left a lot to world's ophthalmology. For many he is the "father of glaucoma", and the nestor of modern and scientific ophthalmology, the one who separated ophthalmology from surgery and is considered to be one of the greatest ophthalmologists of all times. ${ }^{28,29}$

26 Hirschberg J. (1992) History of Ophthalmology. The Reform of Ophthalmology, vol 11. part 1a (Blodi FC, transl.). Bonn: JP Wayenborgh Verlag, 241.

27 Heynold von Graefe B. (1991) Albrecht von Graefe-Mensch und Umwelt. Berlin: Stapp Verlag, p. 89.

28 Kunst B. (2007) Gedenken an Albrecht von Graefe - Die Graefe-Sammlung der DOG am Berliner Medizinhistorischen Museum. In: Deutsche Ophthalmologische Gessellschaft (ed.). Visus und vision-150 Jahre DOG. Köln: Biermann Verlag GmbH, p. 291-307.

29 Perera CA. (1935) Albrecht von Graefe, founder of modern ophthalmology: his life and works. Arch Ophthalmol., 14(5):742-73. 


\section{REFERENCES}

1. Auffarth GU, Krogmann F. (2018) Die Zukunft im Blick: 150 Jahre UniversitätsAugenklinik Heidelberg. Heidelberg: hei BOOKS, p. 49.

2. Cooper SN. (1970) Editorial. Albrecht von Graefe. Indian J Ophthalmol.,18(4):150-3.

3. Draeger J. (1993) Principles of measurements in tonometry at the time of Albrecht von Graefes to D2 mission and self-tonometry. Klin Monatsbl Augenheilkd., 202(1):2-7.

4. Duke-Elder S. (1969) Diseases of the lens and vitreous; Glaucoma and hypotony. System of Ophthalmology, vol 11. London: Henry Kimpton, p. 615.

5. Goldmann H. (1971) Albrecht von Graefe and glaucoma. Graefes Arch Clin Exp Ophthalmol., 181(2):94-106.

6. Harms H. (1971) The importance of Albrecht von Graefe's work on the examination of the visual field. Graefes Arch Clin Exp Ophthalmol., 181(2):120-9.

7. Herde J. (2007) Die Nachfahren der von Graefe- und Graefe-Familien. In: Deutsche Ophthalmologische Gessellschaft (ed.). Visus und vision-150 Jahre DOG. Köln: Biermann Verlag GmbH, p. 309-53.

8. Heynold von Graefe B. (1991) Albrecht von Graefe-Mensch und Umwelt. Berlin: Stapp Verlag, p. 89.

9. Hirschberg J. (1906) Albrecht von Graefe. Leipzig: Wilhelm Weicher, p. 19.

10. Hirschberg J. (1992) History of Ophthalmology. The Reform of Ophthalmology, vol 11. part 1a (Blodi FC, transl.). Bonn: JP Wayenborgh Verlag, 241.

11. Hoffmann-Axthelm W. (1979) Die Familie von Graefe und ihre Villa Finkenherd im Berliner Tiergarten. Mitteilungen des Vereins für die Geschichte Berlins, $66(21): 322-34$.

12. Jähne M. (1988) Carl Ferdinand von Grefe (1787-1840) und seine Relevanz für die Augenheilkunde. Klin Monatsbl Augenheilkd., 193(3):310-4.

13. Kazimirski J. (1995) Albrecht von Graefe Augenklinik. Ophthalmo-Chirurgie, 7:171-9.

14. Kerr C. (2008) Scientific ophthalmology owes its beginnings to short life of Albrecht von Graefe. Eurotimes, 13:54.

15. Kunst B. (2007) Gedenken an Albrecht von Graefe - Die Graefe-Sammlung der DOG am Berliner Medizinhistorischen Museum. In: Deutsche Ophthalmologische Gessellschaft (ed.). Visus und vision-150 Jahre DOG. Köln: Biermann Verlag GmbH, p. 291-307.

16. Michaelis E. (1877) Albrecht von Graefe. Sein Leben und Wirken. Berlin: G. Reimer, p. 35. 
17. Münchow W. (1978) Albrecht von Graefe. Leipzig: BG Teubner Verlagsgesellschaft, p. 60.

18. Perera CA. (1935) Albrecht von Graefe, founder of modern ophthalmology: his life and works. Arch Ophthalmol., 14(5):742-73.

19. Ravin JG. (1999) Sesquicentennial of the ophthalmoscope. Arch Ophthalmol., 117(12):1634-8.

20. Remky H. (1995) Albrecht von Graefe. Facets of his work. On the occasion of the 125th anniversary of his death (20 July 1870). Graefes Arch Clin Exp Ophthalmol., 233(9):537-48.

21. Rohrbach JM. (2013) Albrecht von Graefe. In: Schilp T, Rohrbach JM (eds.). Albrecht von Graefe an Frans Cornelis Donders: Briefe 1852 bis 1970. Essen: Klartext, p. 21-56.

22. Samelson A. (1866) Von Graefe's Eye Clinic. Am J Med Sci., 52(103):259-61.

23. Snyder C. (1965) Dr. Albrecht von Graefe in Behrenstrasse will treat free of charge the eye diseases of the poor. Arch Ophthalmol., 74(4):545-8.

24. Tan SY, Zia JK. (2007) Albrecht von Graefe (1828-1870): founder of scientific ophthalmology. Syngapore Med J., 48:797-8.

25. Ullman EV. (1954) Albrecht von Graefe: The man in his time. Am JOphthalmol., 38(4):525-43.

26. Ullman EV. (1954) Albrecht von Graefe: The man in his time. Am JOphthalmol., 38(6):791-809.

27. Wachholz EA. (1972) Cataract knife and cataract incision from Jean Jacques Daviel to Albrecht von Graefe. Ber Zusammenkunft Dtsch Ophthalmol Ges., 71:709-12. 


\section{SAŽETAK}

O glasovitom oftalmologu Albrechtu von Graefeu mnogo je rečeno i napisano. Ovaj rad daje detaljan opis mjesta u kojima je živio i prakticirao oftalmologiju u Berlinu jer se o tome malo pisalo i nikada na jednome mjestu.

Von Graefeu je rođen 1828. u vili Finkenherd u sjeverozapadnom dijelu Tiergartena $u$ Berlinu. Živio je u Behrenstrasse, jednoj od otmjenijih ulica u Berlinu, gdje je i započeo I850. svoju oftalmološku praksu. Poslije, I852., osnovao je poznatu privatnu očnu kliniku u Karlstrasse 46 u kojoj je liječio brojne očne bolesnike i educirao mnoge značajne oftalmologe $i$ kirurge. Nekoliko je puta mijenjao mjesto boravka tako da je stanovao i u aveniji Unter den Linden i Bellevuestrasse blizu Potsdamer Platza.

Godine I868. postao je šef Očne klinike u bolnici Charité. Otad do smrti ז87o. živio je u prostranoj kući u Viktoriastrasse.

Iako je Albrecht von Graefe živio samo četrdeset dvije godine, puno je putovao, ali je najveći dio života proveo u Berlinu. Graefe je dao velik doprinos oftalmologiji te se smatra „ocem glaukoma" i nestorom moderne oftalmologije.

Ključne riječi: Albrecht von Graefe; oftalmologija; povijest; 19. stoljeće; Berlin 